Scholarship Repository

University of Minnesota Law School

Articles

Faculty Scholarship

2005

\title{
Corporate Human Rights Responsibilities
}

David Weissbrodt

University of Minnesota Law School, weiss001@umn.edu

Follow this and additional works at: https://scholarship.law.umn.edu/faculty_articles

Part of the Law Commons

\section{Recommended Citation}

David Weissbrodt, Corporate Human Rights Responsibilities, 6 ZEITSCHRIFT FUR WIRTSCHAFTS- UND UNTERNEHMENSETHIK (JOURNAL OF BUSINESS, ECONOMICS \& ETHICS) 279 (2005), available at https://scholarship.law.umn.edu/faculty_articles/242.

This Article is brought to you for free and open access by the University of Minnesota Law School. It has been accepted for inclusion in the Faculty Scholarship collection by an authorized administrator of the Scholarship Repository. For more information, please contact lenzx009@umn.edu. 


\title{
Corporate Human Rights Responsibilities
}

\author{
DAVID WEISSBRODT
}

This article begins with a discussion of why one should be concerned or at least interested in the buman rights conduct of corporations. Hence, the first part of the article presents a couple of historical and current situations which require attention and standard-setting. The second part focuses on past efforts of international law and particularly international human rights law to deal with such nonstate actors as corporations. The third part discusses five major attributes of the U.N. Human Rights Norms which built upon the previous efforts to deal with the human rights conduct of corporations. The fourth part traces the process by which the Norms were prepared and are now being considered by the U.N. Commission on Human Rights. The fifth part identifies three principal issues raised by the opponents to the Norms. And the article concludes with an account of how the Norms are already being used by businesses, mutual funds, and others.

Keywords: corporations, human rights, social-responsibility, standard-setting

\section{Historical and Current Human Rights Concerns as to the Activities of Business}

This year marks the $60^{\text {th }}$ anniversary of the initiation of the Nuremberg trials of the Major War Criminals after World War II. ${ }^{1}$ During the following trials German industrialist Alfried Krupp and nine other officials of the huge Krupp industrial firm were convicted of charges relating, inter alia, to the use of slave labor. During that era the Krupp firm became an inextricable part of the German policy for occupied countries such as France, Norway, and Poland. The Krupp corporate officers received terms of imprisonment with Krupp himself being sentenced to twelve years imprisonment. In

David Weissbrodt. Regents Professor and Fredrikson \& Byron Professor of Law, University of Minnesota. The author served as a member of the U.N. Sub-Commission on the Promotion and Protection of Human Rights during the period 1996-2003. He was elected the Chairperson of the Sub-Commission for the year 2001-02. He also served as a member of the Sub-Commission's Working Group on the Working Methods and Activities of Transnational Corporations. This article, however, reflects his views and not necessarily the positions of those institutions. The author wishes to thank Muria Kruger, Bridget Marks, and Mary Rumsey for their assistance in preparing this article. University of Minnesota, Human Rights Center, Mondale Hall N-120, 229-19th Avenue South, Minneapolis, MN 55455, USA, phone: ++1-612-625-5027, e-mail: weiss001@umn.edu.

1 Agreement for the Prosecution and Punishment of the Major War Criminals of the European Axis, 82 U.N.T.S. 279, entered into force Aug. 8, 1945, http://www1.umn.edu/humanrts/instree/ imt1945.htm. 
addition, all his properties - public and private - were forfeited. ${ }^{2}$ In a subsequent case 24 directors and officers of the German conglomerate I.G. Farben Industry were convicted for, inter alia, slave labor and for designing and producing poison gas used in the concentration camps of the Third Reich. ${ }^{3}$ Thirteen I.G. Farben corporate defendants were found guilty and were sentenced to terms of imprisonment.

Looking at a more recent situation of corporate greed and crimes against humanity: In the brutal war in which more than three million lives have been lost over the past seven years in the Democratic Republic of Congo, companies have engaged in forced labor practices reminiscent of World War II. ${ }^{4}$ The U.N. Panel of Experts on the Illegal Exploitation of National Resources and Other Forms of Wealth of the Democratic Republic of the Congo identified over 80 companies from developed nations ${ }^{5}$ that exploited Congolese natural resources during the war. Some of those companies have used forced labor; others have facilitated the transfer of weapons to the warring parties which have been implicated in committing war crimes. The companies were evidently motivated by the mineral wealth of the Democratic Republic of the Congo (DRC). For example, mineral columbo tantaline ("coltan") is found in the eastern DRC and tantalum can be extracted from that ore for use in the production of electronic components commonly used in cell phones. Because of increases in the price of coltan in world markets, some rebel groups and unscrupulous businesses forced

2 United States of America v. Alfried Felix Alwyn Krupp von Bohlen und Halbach, "The Krupp Case", 9 Trials of War Criminals Before the Nuremberg Military Tribunals Under Control Council Law No. 10 (1950). As the trial court said in Doe v. Unocal, 110 F. Supp.2d 1294, 1310 (C.D. Cal. (2000), aff'd, -- F.3d --, 2002 WL 31063976 (9th Cir. 2002), “The Tribunal found the defendants guilty of employing slave labor because their will was not overpowered by the Third Reich 'but instead coincided with the will of those from whom the alleged compulsion emanated.' $I d$. at 1439. Moreover, the 'Krupp firm had manifested not only its willingness but its ardent desire to employ forced labor.' Id. at 1440".

3 United States of America v. Carl Krauch "The Farben Case", 8 Trials of War Criminals Before the Nuremberg Military Tribunals Under Control Council Law No. 10 (1952); Case no. 57, "the I .G. Farben Trial“, US military Tribunal, Nuremberg, 14 Aug. 1947-29 July 1948, 10 Law Reports of Trials of War Criminals 1 (1952). "While the Farben organisation, as a corporation, is not charged under the indictment with committing a crime and is not the subject of prosecution in this case, it is the theory of the prosecution that the defendants individually and collectively used the Farben organisation as an instrument by and through which they committed the crime enumerated in the indictment. All the members of the Vorstand or governing body of Farben who were such at the time of the collapse of Germany were indicted and brought to trial". 8 Trials of War Criminals Before the Nuremberg Military Tribunals 1108 (1952).

Final Report of the Panel of Experts on the Illegal Exploitation of National Resources and Other Forms of Wealth of the Democratic Republic of the Congo, U.N. Doc. S/2002/1146 (2002), http://www.natural-resources.org/minerals/law/docs/pdf/N0262179.pdf. See also All Party Parliamentary Group on the Great Lakes Region, The OECD Guidelines for Multinational Enterprises and the DRC (February 2005).

5 That is, from thirty developed nations of North America, Western Europe, and Japan that are members of the Organization for Economic Cooperation and Development (OECD). 
farmers and their families to leave their agricultural lands and compelled them to work in coltan mines. ${ }^{6}$

Companies may violate human rights not only in periods of armed conflict ${ }^{7}$ but also by employing child laborers, discriminating against certain groups of employees - such as union members and women -, attempting to repress independent trade unions and discourage the right to bargain collectively, failing to provide safe and healthy working conditions, and limiting the broad dissemination of appropriate technology and intellectual property. They also dump toxic wastes and their production processes may have consequences for the lives and livelihoods of neighboring communities. One of the most visible examples of corporate human rights abuses occurred in Bhopal, India, in 1984, when forty-one tons of methyl isocyanate were released from a plant owned by Union Carbide Corporation (Amnesty International 2005). At least 15,000 people were killed, and more than 170,000 people were disabled. Local water and soil still remain severely contaminated, and birth defects continue to be reported. Five years after the disaster, Union Carbide was held legally accountable by the Indian Supreme Court, which ordered the company to pay civil claims of $\$ 470$ million. Twenty years after the disaster, however, many victims have still not received any compensation. Union Carbide has refused to release information about the chemicals that caused the harm, including the results of tests completed on the health effects of the spillage. In 2001, Union Carbide became a subsidiary of Dow Chemical, which claims that it has no responsibility for the prior actions of its new subsidiary.

At the same time corporations bring new jobs, capital, and technology capable of improving working conditions and raising local living conditions. They certainly have the capacity to assert a positive influence in fostering development and achieving prosperity.

Whether one thinks of businesses as critical for the prosperity and economic success of the community or one focuses upon the problems they may cause, there is certainly no doubt that companies are powerful forces in this community, around the nation, and throughout the world. The 300 largest corporations account for more than one-quarter of the world's productive assets (Gabel/Bruner 2003: 9). ${ }^{8}$ For example, General Motors' sales in a single year are greater than the gross national product of 179 countries, including Malaysia, Norway, Saudi Arabia, and South Africa (Gabel/Bruner 2003: supra note 9, at 2). Transnational corporations (TNCs) hold

\footnotetext{
6 The U.N. Panel brought to the attention of banks several companies and individuals that had been engaged in illegal activities and the banks closed the relevant accounts. The U.N. Panel also worked closely with the National Contact Points of the Organization for Economic Cooperation and Development to seek information and to resolve problems that were identified.

7 "In the field of human rights, there are growing expectations that corporations should do everything in their power to promote universal human rights standards, even in conflict situations where governance structures have broken down" (Clapham/Jerbi 2001); See also Bantekas (2004); Deva (2003); Deva (2004); Kinley/Tadaki (2004); Koh (2004); Paust (2002); Petersmann (2002); Taylor (2004).

8 Citing A Survey of Multinationals, Economist, Mar. 27, 1993, at 9.
} 
ninety percent of all technology and product patents worldwide, ${ }^{9}$ and are involved in seventy percent of world trade (Athanasiou 1996; Korten 1995). TNCs directly employ 90 million people (of whom some 20 million live in developing countries) and produce $25 \%$ of the world's gross product. The top 1,000 of these TNCs account for 80 percent of the world's industrial output. ${ }^{10}$ TNCs are active in some of the most dynamic sectors of national economies, such as extractive industries, telecommunications, information technology, electronic consumer goods, footwear and apparel, transport, banking and finance, insurance, and securities trading (Gabel/Bruner 2003: supra note 9 , at 34$) \cdot{ }^{11}$

\section{Application of International Human Rights Law to Non-State Actors such as Corporations}

Given their importance in the world, it is really remarkable that corporations have not received more attention in the evolution of international law and particularly international human rights law. International law and human rights law have principally focused on protecting individuals from violations by governments. There has been increasing attention, however, to individual responsibility for war crimes, genocide, and other crimes against humanity, based on the Nuremberg tribunals in the 1940s (Gabel/Bruner 2003: supra note 1); the criminal tribunals established in the 1990s for the former Yugoslavia ${ }^{12}$ and Rwanda ${ }^{13}$; and the International Criminal Court ${ }^{14}$ which has now been accepted by 97 nations (although not the United States)..$^{15}$

In addition to State responsibility and individual criminal responsibility, international humanitarian law has placed direct obligations on armed opposition groups - particularly in the context of civil wars and other non-international armed conflicts. ${ }^{16}$ Inter-

9 “TNCs reportedly control $90 \%$ of the world's technology patents" Kwon (1995), citing Asavaroengchai (1994). Id. at 7, citing United Nations Conference on Trade and Development (UNCTAD), World Investment Report 2001 at 9 (2001).

11 And analysis of TNCs' activities in various economic sectors at 36-119 (describing TNCs in motor vehicle, petroleum and petroleum products, chemical and pharmaceutical, construction, forest and paper products, computers, and other sectors).

12 Statute of the International Tribunal for the Prosecution of Persons Responsible for Serious Violations of International Humanitarian Law Committed in the Territory of the Former Yugoslavia since 1991, U.N. Doc. S/25704 at 36, annex (1993) and S/25704/Add.1 (1993), adopted by Security Council on 25 May 1993, U.N. Doc. S/RES/827 (1993).

13 Statute of the International Tribunal for Rwanda, adopted by S.C. Res. 955, U.N. SCOR, 49th Sess., 3453d mtg. at 3, U.N. Doc. S/RES/955 (1994), 33 I.L.M. 1598, 1600 (1994).

14 Rome Statute of the International Criminal Court, 2187 U.N.T.S. 3, entered into force July 1, 2002. The International Criminal Court has jurisdiction only over natural persons (including corporate officers), but not over legal persons, such as corporations. Id. Art. 25. See Clapham (2000).

15 http://www.iccnow.org/countryinfo/worldsigsandratifications.html.

16 See, e.g., Geneva Convention relative to the Protection of Civilian Persons in Time of War, 75 U.N.T.S. 287, entered into force Oct. 21, 1950, Common Art. 3. 
national criminal law has also been applied to terrorists ${ }^{17}$ and traffickers in human beings. ${ }^{18}$ Yet, there is one category of very powerful non-state actors that has not received sufficient attention, that is, transnational corporations and, indeed, all businesses.

Some human rights treaties and other law-making instruments may be interpreted to apply to businesses. Most prominently, one can find a relevant passage in the Universal Declaration of Human Rights (1948: 71) - that is, the primary non-treaty instrument that in 1948 first established an authoritative, worldwide definition of human rights. While the Universal Declaration principally focuses on the obligations of states, it also mentions the responsibilities of individuals and "every organ of society" (Id. preamble), which includes businesses. The Universal Declaration thus provides

a common standard of achievement for all peoples and all nations, to the end that every individual and every organ of society, keeping this Declaration constantly in mind, shall strive by teaching and education to promote respect for these rights and freedoms and by progressive measures, national and international, to secure their universal and effective recognition and observance (...) (Id.).

Under the International Covenant on Civil and Political Rights (1966: 52), a treaty that has been ratified by 154 nations including the United States, each State party "undertakes to respect and to ensure to all individuals within its territory and subject to its jurisdiction the rights recognized in the present Covenant (...)" (Id. Art. 2). Accordingly, if a corporation endangers the rights of an individual, the State has a duty to ensure respect of human rights and thus to take preventative action. In addition, the Covenant indirectly covers the responsibilities of companies in declaring:

Nothing in the present Covenant may be interpreted as implying for any State, group or person any right to engage in any activity or perform any act aimed at

17 See, e.g., Convention against the Taking of Hostages, 1316 U.N.T.S. 205, entered into force June 3, 1983; Convention for the Suppression of Terrorist Bombings, U.N. Doc. A/RES/52/164 (1997), 37 I.L.M. 249, entered into force May 23, 2001; Convention for the Suppression of the Financing of Terrorism, U.N. Doc. A/RES/54/109 (1999), 39 I.L.M. 270, entered into force April 1, 2002; Convention for the Suppression of Unlawful Acts against the Safety of Civil Aviation, Sept. 23, 1971, 974 U.N.T.S. 177, 24 U.S.T. 564, 10 I.L.M. 1151, entered into force Jan. 26, 1973; Convention for the Suppression of Unlawful Acts against the Safety of Maritime Navigation, Mar. 10, 1988, 1678 U.N.T.S. 221, 27 I.L.M. 668, entered into force Mar. 1, 1992; Convention for the Suppression of Unlawful Seizure of Aircraft, 860 U.N.T.S. 105, entered into force Oct. 14, 1971.

18 Convention Against Transnational Organized Crime, G.A. res. 55/25, annex I, 55 U.N. GAOR Supp. (No. 49) at 44, U.N. Doc. A/45/49 (Vol. I) (2001), not entered into force; Convention for the Suppression of the Traffic in Persons and of the Exploitation of the Prostitution of Others, 96 U.N.T.S. 271, entered into force July 25, 1951; Protocol Against the Smuggling of Migrants by Land, Sea and Air, Supplementing the United Nations Convention Against Transnational Crime, G.A. res. 55/25, annex III, 55 U.N. GAOR Supp. (No. 49) at 65, U.N. Doc. A/45/49 (Vol. I) (2001); Protocol to Prevent, Suppress and Punish Trafficking in Persons, Especially Women and Children, Supplementing the United Nations Convention Against Transnational Organized Crime, G.A. res. 55/25, annex II, 55 U.N. GAOR Supp. (No. 49) at 60, U.N. Doc. A/45/49 (Vol. I) (2001). 
the destruction of any of the rights and freedoms recognized herein (...) (Id.

Art. 5(1)).

Other treaties express the idea that the State can ensure the respect of human rights by non-state entities. For example, Article 2(d) of the International Convention on the Elimination of All Forms of Racial Discrimination (1966: 47) (ratified by 170 nations including the United States) requires States parties to "prohibit and bring to an end, by all appropriate means, including legislation (...), racial discrimination by any persons, group or organization (...)" (Id. Art. 2(1)(d)). Hence, States have the indirect responsibility to prevent racial discrimination by corporations. Similarly, Article $2(\mathrm{e})$ of the Convention on the Elimination of All Forms of Discrimination against Women (1981: 193) (ratified by 179 nations, but not the United States) requires States parties to "take all appropriate measures to eliminate discrimination against women by any person, organization or enterprise (...) (Id. Art 2(e)). The Committee on the Elimination of Discrimination Against Women (1993: 1) has interpreted that provision as including the responsibility of States "for private acts if they fail to act with due diligence to prevent violations of rights or to investigate and punish acts of violence, and for providing compensation."

Accordingly, human rights treaties and interpretive pronouncements of treaty bodies provide for at least indirect human rights responsibilities of businesses. ${ }^{19}$ The persistent occurrence of human rights abuses by businesses, however, has prompted several international efforts to define the direct responsibilities of companies. For example, the U.N. Commission on Transnational Corporations unsuccessfully attempted to draft an international code of conduct for TNCs in the 1970s and 1980s. ${ }^{20}$ The Organization for Economic Cooperation and Development (OECD) undertook a similar effort in 1976 (updated in 2000) when it established its Guidelines for Multinational Enterprises to promote responsible business conduct consistent with applicable laws, but the OECD Guidelines mentioned human rights only once in a single paragraph. ${ }^{21}$ In 1977 the International Labor Organization (ILO) developed its Tripartite Declara-

19 For example, in interpreting the International Covenant on Civil and Political Rights, the Human Rights Committee observed, "Article 17 provides for the right of every person to be protected against arbitrary or unlawful interference with his privacy, family, home or correspondence as well as against unlawful attacks on his honour and reputation. In the view of the Committee this right is required to be guaranteed against all such interferences and attacks whether they emanate from State authorities or from natural or legal persons“. Human Rights Committee, General Comment 16 (Twenty-third session, 1988), Compilation of General Comments and General Recommendations Adopted by Human Rights Treaty Bodies, U.N. Doc. HRI $\backslash$ GEN $\backslash 1 \backslash$ Rev.1 at 21, para. 1 (1994).

20 See Development and International Economic Cooperation: Transnational Corporations, U.N. Doc. E/1990/94 (1990). See also United Nations Draft International Code of Conduct on Transnational Corporations, 23 I.L.M 626 (1984).

21 Organization for Economic Cooperation and Development, Guidelines for Multinational Enterprises, 15 I.L.M. 967 (1976). The OECD updated these Guidelines in 2000. OECD Guidelines for Multinational Enterprises, Revision 2000, http://www.oecd.org/dataoecd/56/36/ 1922428.pdf. 
tion of Principles Concerning Multinational Enterprises, which calls upon businesses to follow the relevant labor conventions and recommendations and which was updated in 2000.22

Further, in January 1999, U.N. Secretary-General Kofi Annan proposed a "Global Compact" of shared values and principles at the World Economic Forum in Davos. ${ }^{23}$ The original Global Compact asked businesses voluntarily to support and adopt nine very succinctly expressed core principles, which are divided into categories dealing with general human rights obligations, standards of labor, and standards of environmental protection. In 2004 the Global Compact added a tenth core principle on corruption. ${ }^{24}$ The ILO, OECD, and Global Compact initiatives all indicate that they are voluntary, although the $\mathrm{ILO}^{25}$ and the $\mathrm{OECD}^{26}$ have established rarely used mechanisms for interpreting their guidelines (Kinley/Tadaki 2004).

In addition, scrutiny of the activities of global businesses by civil society and an emerging concern of companies themselves for social responsibility have since the 1980 s led hundreds of companies and several industry associations to adopt voluntary codes of conduct (Amnesty International/The Prince of Wales Business Leaders Forum 2000). ${ }^{28}$ Some publicly spirited business people, such as the Minnesota Business Partnership and later the Caux Roundtable, developed voluntary principles applicable to a broad range of companies. Although there is a very important educational value in company codes and other voluntary initiatives, they often are very vague in regard to human rights commitments and lack mechanisms for assuring continuity or implementation. For example, only eighty-five corporations have even mentioned human rights in their respective company codes. ${ }^{29}$ Accordingly, one can

22 International Labor Organization, Tripartite Declaration of Principles concerning Multinational Enterprises and Social Policy, 17 I.L.M. 422, para. 6 (1978), http://www.ilo.org/public/english/ employment/multi/index.htm.

23 Secretary-General Kofi Annan, Address at the World Economic Forum in Davos, Switzerland (Jan. 31, 1999), in U.N. Doc. SG/SM/6448 (1999).

24 http://www.unglobalcompact.org/Portal/Default.asp?. The principles are that businesses should: (1) support and respect the protection of internationally proclaimed human rights within their sphere of influence; (2) make sure they are not complicit in human right abuses; (3) uphold the freedom of association and the effective recognition of the right to collective bargaining; (4) eliminate all forms of forced and compulsory labor; (5) abolish child labor; (6) eliminate discrimination in respect of employment and occupation; (7) support a precautionary approach to environmental challenges; (8) undertake initiatives to promote greater environmental responsibility; (9) encourage the development and diffusion of environmentally friendly technologies; and (10) work against all forms of corruption, including extortion and bribery.

25 http://www.ilo.org/public/english/employment/multi/dispute.htm.

26 http://www.oecd.org/document/60/0,2340,en_2649_34889_1033116_1_1_1_1,00.html, http:// www.oecd.org/document/43/0,2340,en_2649_34889_2074731_1_1_1_1,00.html.

28 See also http://www1.umn.edu/humanrts/business/codes.html.

29 http://www.business-humanrights.org/Categories/Companypolicysteps/Policies/Companieswith humanrightspolicies. 
summarize the situation when the U.N. Sub-Commission on the Promotion and Protection of Human Rights entered this field as follows: There existed significant concerns about the conduct of transnational corporations and other businesses. The OECD, an institution of 30 governments from only developed countries, had produced voluntary guidelines with a rudimentary implementation mechanism, but those guidelines only mentioned human rights once and lacked the support of a worldwide institution such as the United Nations. The ILO had issued another overlapping set of guidelines focusing almost exclusively on labor issues. Companies, industry-groups, and nongovernmental organizations had prepared their own voluntary guidelines, but they rarely mentioned human rights, generally lacked implementation procedures, and could be put up on the World Wide Web one day and taken down the next.

\section{The U.N. Human Rights Norms for Business as the Next Logical Step}

Building upon the previous initiatives regarding corporate social responsibility, in August 2003 the U.N. Sub-Commission on the Promotion and Protection of Human Rights approved ${ }^{31}$ the Norms on the Responsibilities of Transnational Corporations and Other Business Enterprises with Regard to Human Rights (2003). ${ }^{32}$ There are at least five significant attributes of the Norms that should be identified. First, the Norms evince a strong commitment that nothing in the Norms shall diminish the human rights obligations of governments. Accordingly, in its first and most important operative paragraph, the Norms establish that

States have the primary responsibility to promote, secure the fulfilment of, respect, ensure respect of and protect human rights recognized in international as well as national law, including ensuring that transnational corporations and other business enterprises respect human rights. Within their respective spheres of activity and influence, transnational corporations and other business enterprises have the obligation to promote, secure the fulfilment of, respect, ensure respect of and protect human rights recognized in international as well as national law, including the rights and interests of indigenous peoples and other vulnerable groups (Id. para 1).

This core provision of the Norms further deals with a second issue that was considered not only in preparing the Norms, but also arose in preparing the ILO, ${ }^{33} \mathrm{OECD},{ }^{34}$

31 Sub-Commission resolution 2003/16, Responsibilities of transnational corporations and other business enterprises with regard to human rights, U.N. Doc. E/CN.4/Sub.2/2003/L.11 at 52 (2003), http://www1.umn.edu/humanrts/links/res2003-16.html.

32 See Commentary on the Norms on the Responsibilities of Transnational Corporations and Other Business Enterprises with Regard to Human Rights (2003).

Paragraph 11 of the ILO Tripartite Declaration provides that "[m]ultinational and national enterprises, wherever the principles of this Declaration are relevant to both, should be subject to the same expectations in respect of their conduct in general and their social practices in particular". International Labor Organization, Tripartite Declaration of Principles concerning Multinational Enterprises and Social Policy, supra note 37, para. 11. 
and Global Compact ${ }^{35}$ guidelines, that is, should these standards apply only to TNCs or to all businesses. On the one hand, most media attention has focused on the activities and misdeeds of major corporations, such as Enron, Union Carbide, and Worldcom. Further, TNCs have the mobility and power to evade national laws and enforcement, because they can relocate or use their political and economic clout to pressure governments to ignore corporate abuses. ${ }^{36}$

If one applies human rights standards only to TNCs, however, that differential treatment could be considered discriminatory. Further, it is not easy to define a transnational corporation and there is a risk that sophisticated corporate lawyers will be able to structure any business so as to avoid the application of international standards. The Norms use one of the most comprehensive definitions of transnational corporation, that is, "an economic entity operating in more than one country or a cluster of economic entities operating in two or more countries - whatever their legal form, whether in their home country or country of activity, and whether taken individually or collectively" 37 In the globalized economy of today, however, that definition is not really adequate. For example, a company might employ only 200 workers in Zurich and own only a single very popular trademark. The company might contract with shirt manufacturers in China and India to purchase shirts and put the trademark on the front pocket. The Zurich company could then agree with a wholesaler to handle the transportation and distribution of the shirts for sale through retailers in Europe and the United States. The Zurich company could retain an advertising agency in London and New York to promote the sales worth many millions of dollars, pounds, euros, and eventually Swiss francs. In a real sense the Zurich company should be considered to be a transnational corporation even though it has assets and employees in only one city.

Accordingly, the Norms apply not only to TNCs, but also to national companies and local businesses in that each will be responsible according to "their respective spheres of activity and influence." This approach balances the need to address the power and responsibilities of TNCs, and to level the playing field of competition for all businesses, while not being too burdensome on very small companies.

34 The OECD Guidelines extend to domestic enterprises ("multinational and domestic enterprises are subject to the same expectations in respect of their conduct wherever the Guidelines are relevant to both"). OECD Guidelines for Multinational Enterprises, Revision 2000, supra note 36, para. I-4.

35 The Global Compact is aimed at "businesses", rather than multinational or domestic enterprises in particular. UN Global Compact, supra note 38.

36 (Grossman/Bradlow 1993) (stating that "The fact that they have multiple production facilities means that [transnational corporations] can evade state power and the constraints of national regulatory schemes by moving their operations between their different facilities around the world“).

37 Norms, supra note 46, para. 20. 
A third significant attribute of the Norms and the related Commentary ${ }^{38}$ is that they have a very broad and comprehensive approach to human rights as compared with the ILO Guidelines that focus on labor standards, the OECD Guidelines that mention human rights only once, and the Global Compact that contain ten short sentences. The Norms comprise 23 paragraphs and are augmented by a more detailed Commentary to reflect the source of the principal provisions and to describe how the provisions apply to companies. As the most comprehensive set of standards so far developed, the Norms and Commentary require TNCs and other business enterprises to respect the right to equality of opportunity and treatment; the right to security of persons; the rights of workers, including a safe and healthy work environment and the right to collective bargaining; respect for international, national, and local laws and the rule of law; a balanced approach to intellectual property rights and responsibilities; transparency and avoidance of corruption; respect for the right to health as well as other economic, social, and cultural rights; other civil and political rights; consumer protection; and environmental protection. In respect to each of those subjects, the Norms principally reflect, restate, and refer to existing international norms.

While the Norms apply to all companies, it should be noted as a fourth attribute that the Norms are not legally binding. Treaties and customary international law can be considered to be binding, but the Norms are similar to many other U.N. declarations, principles, guidelines, standards, and resolutions that interpret existing law and summarize international practice without reaching the status of a treaty. Eventually, of course, the Norms could be considered recommendations or what international law scholars call "soft law" and could also provide the basis for drafting a human rights treaty on corporate social responsibility.

The final attribute of the Norms is that they do endeavor to include five basic implementation procedures and anticipate that they may later be supplemented by other techniques and processes. First, the Norms anticipate that companies will adopt their own internal rules of operation to assure the protections set forth in this instrument. Second, the Norms indicate that businesses are expected to assess their major activities in light of its provisions. Third, compliance with the Norms is subject to monitoring that is independent, transparent, and includes input from relevant stakeholders. Fourth, if companies violate the Norms and cause damage, the Norms call for compensation, return of property, or other reparations. And fifth, recognizing the significant responsibility of governments, the Norms call upon those governments to establish a framework for application of the Norms.

\section{Process by which the Norms were Prepared and are now being Considered by the Commission on Human Rights}

The five-member U.N. Working Group on the Working Methods and Activities of Transnational Corporations began preparing the Norms in August 1999 (Weiss-

38 Commentary on the Norms on the Responsibilities of Transnational Corporations and Other Business Enterprises with Regard to Human Rights (2003). 
brodt/Kruger 2003). The Working Group was comprised of five human rights experts from Africa, Asia, Eastern Europe, Latin America, and Western Europe and Other Countries (including the U.S.) and was chaired by a Senegalese judge who had initially proposed the creation of the Working Group. The Working Group held four public hearings on the Norms during the summers of 2000, 2001, 2002, and 2003. The meetings of the Working Group were open and were attended by a couple hundred human rights experts and representatives of governments, nongovernmental advocacy organizations, businesses, unions, and intergovernmental organizations.

In addition, the Ford Foundation offered to pay for an international seminar in Geneva in March 2001 to get more input from representatives of businesses - including BP, Novartis, Novo Nordisk, Reebok, South African Breweries, the International Business Leaders Forum, the International Organization of Employers, and various socially responsible mutual funds (including Calvert Group Ltd. and ISIS) as well as unions, NGOs (Amnesty International, Christian Aid, Human Rights First, Human Rights Watch, etc.), the scholarly community, and other interested persons. The rapporteur for the seminar was the Senior Legal Counsel in Nokia's Networks division, based in Europe. Another such seminar was held in March 2003 and both of these meetings were very much involved in reshaping the document and in submitting proposals for consideration at the public hearings of the Working Group. Further drafts were presented at public sessions in the summers of 2002 and 2003 as well as during another seminar in March 2003 in Geneva.

The Working Group also posted the various drafts on the World Wide Web ${ }^{39}$ and issued them in U.N. publications, so that they were accessible and open to comment. All of the comments received have been taken into account in the drafting process.

After this open and inclusive drafting process, the Working Group recommended the Norms to the U.N. Sub-Commission and the Sub-Commission unanimously approved the Norms on August 13, 2003. The Sub-Commission sent the Norms to its parent body, the U.N. Commission on Human Rights. Unlike the Sub-Commission, which is comprised of 26 more-or-less independent experts from 26 different nations representing all the regions of the world (including Algeria, Brazil, Chile, China, Cuba, Ethiopia, India, France, Japan, Morocco, Mozambique, Norway, Pakistan, Romania, Russia, Senegal, South Korea, United Kingdom, and the United States), the Commission is constituted by 53 representatives of governments. The Commission ordinarily meets each year from mid-March until the end of April, so that the Norms had their first hearing at the Commission in March-April 2004. The Commission essentially accepted the Sub-Commission's primary procedural recommendation, that is, the Norms should be disseminated broadly to all potentially interested governments, intergovernmental organizations, businesses, unions, nongovernmental organizations, and others, so that comments can be received in time for further consideration by the

39 http://www1.umn.edu/humanrts/links/normsdrafts.html. 
Commission at its March-April 2005 session. $^{40}$ The deadline for comments was September 30, 2004. Over 90 comments were received. ${ }^{41}$ Also, on October 22, 2004, the Office of the High Commissioner for Human Rights, in cooperation with the U.N. Global Compact Office, held a one-day meeting in Geneva on the topic of the responsibilities of business with regard to human rights. In addition to soliciting comments and views so that the High Commissioner's Office could prepare a report for the 2005 session of the Commission on "The responsibilities of transnational corporations and related business enterprises with regard to human rights", (U.N. 2005) the 2004 session of the Commission welcomed the Norms, but at the same time noted that the Commission had not actually asked for the document and that, as a draft before the Commission, the document does not on its own have any legal status. Simultaneously, however, the Commission recognized for the first time in its history that corporate social responsibility and human rights belong on the agenda of the Human Rights Commission. That was quite a success in itself.

It is extraordinarily unlikely that the Commission would act substantively upon the Norms without further drafting and several years of consideration - before the Norms or a success instrument could eventually be submitted to the Economic and Social Council of the United Nations, and ultimately to the General Assembly for adoption. At the same time, however, any of these bodies could adopt the Norms or a

40 U.N. Comm. Human Rts. dec. 2004/116, U.N. Doc. E/CN.4/2004/L.11/Add.7 (2004), http:// www.unhchr.ch/huridocda/huridoca.nsf/e06a5300f90fa0238025668700518ca4/169143c3c10090 15c1256e830058c441/\$FILE/G0413976.pdf.

At its 56th meeting, on 20 April 2004, the Commission on Human rights, taking note of resolution 2003/16 of 13 August 2003 of the Sub-Commission on the Promotion and Protection of Human Rights, taking note also of Sub-Commission document E/CN.4/2003/12/Rev.2 and expressing its appreciation to the Sub-Commission for the work it has undertaken in preparing the draft norms on the responsibilities of transnational corporations and other business enterprises with regard to human rights, which contain useful elements and ideas for consideration by the Commission, decided, without a vote, to recommend that the Economic and Social Council:

Confirm the importance and priority it accords to the question of the responsibilities of transnational corporations and related business enterprises with regard to human rights;

Request the Office of the High Commissioner for Human Rights to compile a report setting out the scope and legal status of existing initiatives and standards relating to the responsibilities of transnational corporations and related business enterprises with regard to human rights, inter alia, the draft norms contained in the above-mentioned document and identifying outstanding issues, to consult with all relevant stakeholders in compiling the report, including States, transnational corporations, employers' and employees' associations, relevant international organizations and agencies, treaty monitoring bodies and non-governmental organizations, and to submit the report to the Commission at its sixth-first session in order for it to identify options for strengthening standards on the responsibilities of transnational corporations and related business enterprises with regard to human rights and possible means of implementation;

Affirm that the document E/CN.4/Sub.2/2003/12/Rev.2 has not been requested by the Commission and, as a draft proposal, has no legal standing, and that the Sub-Commission should not perform any monitoring function in this regard. 
similar standard as their views - carrying some degree of United Nations and thus world support. Obviously, the higher the U.N. institution and the more consensus achieved, the more authoritative would be the imprimatur the Norms should obtain.

At its 2005 session the Commission adopted a resolution ${ }^{42}$ welcoming the High Commissioner's report (U.N. 2005) that in an extraordinarily balanced fashion identified precisely the same number of criticisms of the Norms as it found positive attributes. The Commission also called for the appointment by the Secretary-General of a Special Representative on the issue of human rights and transnational corporations and other business enterprises. The Special Representative will serve for "an initial period of two years" implying that the Commission intends to continue the mandate beyond two years. The Special Representative received the following terms of reference:

(1) To identify and clarify standards of corporate responsibility and accountability for transnational corporations and other business enterprises with regard to human rights;

(2) To elaborate on the role of States in effectively regulating and adjudicating the role of transnational corporations and other business enterprises with regard to human rights, including through international cooperation;

(3) To research and clarify the implications for transnational corporations and other business enterprises of concepts such as "complicity" and "sphere of influence";

(4) To develop materials and methodologies for undertaking human rights impact assessments of the activities of transnational corporations and other business enterprises;

(5) To compile a compendium of best practices of States and transnational corporations and other business enterprises $(\ldots .)^{43}$

The Commission also underlined that

the Special Representative of the Secretary-General should take into account in his or her work the report of the United Nations High Commissioner for Human Rights and the contributions to that report provided by all stakeholders, as well as existing initiatives, standards and good practices $(\ldots.){ }^{44}$

While the resolution does not mention the Norms, it focuses on the High Commissioner's report with regard to the Norms and the resolution underscores "existing initiatives, standards and good practices."

42 C.H.R. res. 2005/69, U.N. Doc. E/CN.4/2005/L.11/Add.7 at 68 (2005), was adopted April 20, 2005, by a vote of 49 in favor, 3 (Australia, South Africa, and the United States) against, and 1 (Burkina Faso) abstaining. The United States called for a vote and explained its vote against the resolution. http://www.humanrights-usa.net/2005/0420Item17TNC.htm.

43 C.H.R. res. 2005/69, U.N. Doc. E/CN.4/2005/L.11/Add.7 at 68 (2005).

44 Ibid.

zfwu 6/3 (2005), 279-297 
On July 28, 2005, U.N. Secretary-General Kofi Annan selected John Ruggie as the Special Representative of the Secretary-General (SRSG) on the issue of human rights and transnational corporations and other business enterprises. ${ }^{45} \mathrm{Mr}$. Ruggie was very influential in the preparation of the Global Compact and was serving as the Special Adviser to the Secretary-General on the Global Compact until he became the SRSG. His appointment will likely strengthen the connection between the Global Compact and the Norms. The Norms might, for example, be considered as an elaboration of the principles set forth in the Global Compact and may provide some guidance as to how the Global Compact might be strengthened and implemented.

\section{Issues that have been raised with regard to the Norms}

There are at least a number of issues that have been raised with regard to the Norms by the International Chamber of Commerce (ICC) and the International Organization of Employers (IOE) - representing some of the largest transnational corporations. While these two organizations were invited to participate in the drafting of the Norms and to some extent did participate, they have been most forceful in trying to stop the Norms since the Sub-Commission approved them in August 2003. The ICC and IOE lobbied hard to kill the Norms at the 2004 Commission sessions, but they did not succeed. They mounted a further lobbying effort for 2005 in which they have raised questions as to whether companies, as non-state actors, can be subjected to human rights standards. That argument ignores the trend of international human rights and humanitarian law towards applying standards not only to states, but also to armed opposition groups, individuals, and other entities. Even the ILO, OECD, and Global Compact guidelines, while voluntary, speak directly to business. While the Norms do take a clear and important step towards applying international standards to all business, that step seems fully justified. Businesses should not be exempted from human rights responsibilities.

Another principal argument of the ICC and IOE has been that they will accept only voluntary guidelines. The voluntary Global Compact has been very successful in educating and encouraging nearly 2,000 companies to join, but it is estimated that there are at least 61,000 TNCs in the world. ${ }^{46}$ What about the other 59,000 companies that are not covered by the Global Compact? The U.N. Human Rights Norms provide an answer to that question.

There is a third argument that the ICC and IOE are reluctant to make at the Commission on Human Rights because they know how unpopular the argument would be in an international forum. That argument has, however, been broached in American academic and political discourse. The argument is mostly closely associated with Professor Milton Friedman who contended that "there is one and only one social

45 U.N. SG/A/934 (2005).

46 United Nations Conference on Trade and Development (UNCTAD), World Investment Report 2004, Annex Table A.12 at 273-75 (2004) (61,582 in 2004), http://www.unctad.org/en/ docs/wir2004_en.pdf. 
responsibility of business - to use its resources and engage in activities designed to increase its profits so long as it stays within the rules of the game, which is to say, engages in open and free competition, without deception or fraud" (Friedman 1962; Friedman 1970). It is interesting to note that even Friedman's view that businesses should not pursue socially desirable objectives excluded two social policies - fraud and competition. Those exceptions may be explained by the need to maintain the quality of the free market that Friedman strenuously advocated. It is doubtful, however, that even Friedman would argue that corporations could pursue profit by committing genocide or using slave labor. Indeed, Friedman would likely have agreed that corporations can only pursue profits in ways that are consistent with legal limitations. That position is consistent with the views of many businesses and business managers who wish to be informed of the law and would be willing to comply with the law. ${ }^{47}$

Focusing only on the self-interest of corporations, however, there is increasing reason to believe that greater respect for human rights by companies leads to greater sustainability in emerging markets ${ }^{48}$ and better business performance. ${ }^{49}$ For example, observance of human rights aids businesses by protecting and maintaining their corporate reputation, ${ }^{50}$ as well as creating a stable and peaceful society in which they can prosper

47 Professor Ronald Coase developed an alternative paradigm to Friedman's understanding of how businesses should act, arguing that businesses are best understood by observing carefully their actual conduct rather than creating artificial models of how they ought to act (see Coase 1988). The past fifteen years have demonstrated that major businesses are, in fact, becoming aware of the interplay between their businesses and their impact on individuals, communities, and the environment; realizing that respect for human rights leads to better business performance; and finding it beneficial to issue their own codes of conduct that go far beyond a narrow profit motive or legal mandates. Hence, the creation of human rights standards that help attract the best and brightest employees, solicit investments from investors who place at least some socially responsible screen on their stock holdings, and attract consumers who prefer to purchase goods made without child labor or unnecessarily soiling the environment are not contrary to the primary purpose of transnational corporations and other business enterprises. The creation of a uniform set of international human right standards would aid in this process by helping to make clear what human rights standards a company should follow and which business enterprises are meeting those standards.

A large-scale study of evidence from developing countries found that emerging market companies gain financially from stability. See International Finance Corporation, Sustainability, Instituto Ethos, Groundbreaking Report Challenges Conventional Wisdom on Role of Business in Emerging Markets, Press Release No. 02/0098, July 17, 2002.

See Cowe (2001) (supporting the proposition that corporate social responsibility has a positive impact on businesses by increasing their potential for competitive advantage and increasing shareholder value through promotion of risk management). See also Farber (2002) (human rights protection properly encourages investment).

50 Research: Corporate Reputation, Brand Strategy, Nov. 2004, at 40, 40 (Ninety-three per cent of senior executives believe that their customers and consumers consider corporate reputation to be extremely important or important. "There has also been a surge in the number of brands taking corporate social responsibility (CSR) seriously"). 
and attract the best and brightest employees. ${ }^{51}$ Moreover, consumers have demonstrated that they are willing to decide upon their purchases of products based on a company's compliance with labor, environmental, and other human rights standards. ${ }^{52}$ Similarly, there is evidence that a growing proportion of investors is seeking to purchase shares in socially responsible companies.

\section{How the Norms are Already Being Used}

While the Norms have yet to acquire legal standing or adoption by the Commission on Human Rights, even in their present format the Norms have begun to be used as the basis for action. For example, some investment institutions have begun applying the Norms as a basis for their efforts to persuade companies to improve their social responsibility. ${ }^{54}$ Some NGOs - such as Amnesty International (2005), Christian Aid

51 MBAs Want to Work for Caring and Ethical Employers, Business \& Env. ISO 14000 Updates, Sept. 2004, at 15, 16 (citing a Stanford study in which "more than $97 \%$ of MBAs in the sample said that they would be willing to forgo financial benefits to work for an organization with a better reputation for corporate social responsibility and ethics"). See also Christopher Avery, Amnesty International, Business and Human Rights in a time of change (Feb. 2000), http://www.business-humanrights.org/Avery-Report.htm; United Nations High Commissioner for Human Rights, Business and Human Rights, http://www.unhchr.ch/global.htm.

52 Andrew Pendleton, The Real Face of Corporate Social Responsibility, Consumer Pol'y Rev., May/Jun2004, at 77, 79 (describing increase in consumer attention to corporate social responsibility). For example, consumer discontent that soccer/footballs were made by child labour led to a consumer boycott forcing the manufacturers to stop using child labor. See Robert J. Liubicic, Corporate Codes of Conduct and Product Labeling Schemes: The Limits and Possibilities of Promoting International Labor Rights Standards Through Private Initiatives, 30 Law and Pol'y Int'l Bus 111 (1998). Another example occurred in regard to the promotion of infant formula in developing countries. Certain companies were encouraging mothers in developing countries to use infant formula instead of breast-milk feeding. The use of infant formula led to increased infant mortality because of lack of clean water and because mothers were not properly instructed on how to use the formula. Once consumers learned about the increased infant mortality, they began boycotting Nestlé products. See Nancy E. Zelman, The Nestlé Infant Formula Controversy: Restricting the Marketing Practice of Multinational Corporations in the Third World, 3 Transnat'l L. 697 (1990).

53 Paul M. Clikeman, Return of the Socially Conscious Corporation, Strategic Fin., Apr. 2004, at 23, 24 (noting investors' demand for information on corporate social responsibility). The ethical market share in the United Kingdom grew 15\% from 1999 to 2000. See Deborah Doane, New Economics Foundation, Taking Flight: The Rapid Growth of Ethical Consumerism (Oct. 2001), http://www.neweconomics.org/default.asp?strRequest=pubs\&strContext=pubdetails\&intPubI $\mathrm{D}=88$. A study in the United States found that one out of every eight professionally managed investment dollars is used in socially responsible investing. See Social Investment Forum, 2001 Report of Socially Responsible Investing Trends in the United States (Nov. 28, 2001), http://www.socialinvest.org/areas/research/trends/2001-Trends.htm.

54 Isis Asset Management (based in London) was involved in the drafting of the Norms, has supported the Norms since their inception, and has used the Norms in their efforts to persuade the companies in which they invested to improve their socially responsible conduct. In August 2004 Isis merged with Foreign \& Commonwealth investment company and the new company, F\&C, has since the merger followed the Isis approach to the Norms. 
(2004), Human Rights First (2003), Human Rights Watch (2004), and AI/OXFAM (2004) - have already been using the Norms as the basis for their advocacy of corporate social responsibility. Some companies, such as Barclay's Bank and Novo Novartis, as well as the International Business Leaders Forum have expressed support for the Norms as a way of understanding their commitment to the Universal Declaration of Human Rights. Several leading companies have begun to road-test the Norms in their own businesses, such as Hewlett-Packard, Novartis, and the other companies that compose the Business Leaders Initiative on Human Rights (2004). Similarly, a major mobile phone company has inserted a standard clause in all its purchasing contracts requiring that all those businesses (about 1,000) with which it contracts or subcontracts must comply with the terms of the U.N. Human Rights Norms for Business. ${ }^{55}$

In conclusion, the UN Human Rights Norms for Business have initiated a process for further identifying, clarifying, and elaborating standards for the responsibility and accountability of transnational corporations and other business enterprises with regard to human rights. That process is occurring both within and outside the United Nations.

\section{References}

AI/ OXFAM (2004): Open Call on Governments in Support of the UN Human Rights Norms for Business (Apr. 7, 2004), AI Index: IOR 42/010/2004, http://web.amnesty.org/library/Index/ENGIOR420102004?open\&of=ENG-398.

Amnesty International (2005): Union Carbide Corporation (UCC), DOW Chemicals and the Bhopal Communities in India, AI Index: ASA 20/005/2005, http://web.amnesty.org/ library/Index/ENGASA200052005?open\&of=ENG-IND.

Amnesty International/ The Prince of Wales Business Leaders Forum (2000): Human Rights: Is It Any of Your Business?, 23.

Asavaroengchai, S. (1994): Seeking a Fair Deal in Global Trade, Bangkok Post, Oct. 19, 1994, 31.

Athanasiou, T. (1996): Divided Planet: The Ecology of Rich and Poor.

Bantekas, I. (2004): Corporate Social Responsibility in International Law, 22 B.U. Int'l L.J. 309.

Business Leaders Initiative on Human Rights (2004): Submission to the Office of the UN High Commissioner for Human Rights Relating to the "Responsibilities of Transnational Corporations and Related Business Enterprises with Regard to Human Rights", http://www.blihr.org/Pdfs/The\%20BLIHR\%20submission\%20to\%20OHCHR.pdf.

Christian Aid (2004): Submission to the Office of the United Nations High Commissioner for Human Rights: Responsibilities of Transnational Corporations and Related Business Enterprises with Regard to Human Rights (Oct. 2004), http://www.christianaid.org.uk/indepth/410unchcr/UNCHCR\%20submission_formatted.pdf.

Clapham, A. (2000): The Question of Jurisdiction Under International Criminal Law Over Legal Persons: Lessons from the Rome Conference on an International Criminal Court,

55 Report of the Sessional Working Group on the Working Methods and Activities of Transnational Corporations on its sixth session, U.N. Doc. E/CN.4/2004/21 at 9 (2004). 
Liability of Multinational Corporations under International Law 143-45 (Menno T. Kamminga and S. Zia-Zarifi eds. 2000).

Clapham, A./ Jerbi, S. (2001): Categories of Corporate Complicity in Human Rights Abuses, 24 Hastings Int'l \& Comp. L. Rev. 339, 339.

Coase, R. H. (1988): The Firm, the Market and the Law.

Commentary on the Norms on the Responsibilities of Transnational Corporations and Other Business Enterprises with Regard to Human Rights (2003): U.N. Doc. E/CN.4/Sub.2/2003/38/Rev.2, http://www1.umn.edu/humanrts/links/commentary-Aug2003.html.

Committee on the Elimination of Discrimination against Women (1993): General Recommendation 19, Violence against women (Eleventh session, 1992), U.N. Doc. A/47/38, reprinted in Compilation of General Comments and General Recommendations Adopted by $\mathrm{Hu}-$ man Rights Treaty Bodies, U.N. Doc. HRI/GEN/1/Rev.6 at 243, para. 9 (2003).

Convention on the Elimination of All Forms of Discrimination against Women (1981): G.A. res. 34/180, 34 U.N. GAOR Supp. (No. 46), U.N. Doc. A/34/46, entered into force Sept. 3, 1981.

Cowe, R. (2001): ABI Research Reports, Investing in Social Responsibility: Risks and Opportunities.

Deva, S. (2003): Human Rights Violations by Multinational Corporations and International Law: Where from Here?, 19 Conn. J. Int'l L. 1.

Deva, S. (2004): Note and Comment, UN's Human Rights Norms for Transnational Corporations and Other Business Enterprises: An Imperfect Step in the Right Direction?, 10 ILSA J. Int'l \& Comp. L. 493.

Farber, D. (2002): Rights as Signals, 31 J. Legal Studies 83, 98.

Friedman, M. (1962): Capitalism \& Freedom, 133.

Friedman, M. (1970): The Social Responsibility of a Business is to Increase Profits, N.Y. Times, Sept. 13, 1970 (Magazine); 32: 125.

Gabel, M./ Bruner, H. (2003): Global Inc.: An Atlas of the Multinational Corporation 5.

Grossman, C./ Bradlow, D. D. (1993): Are We Being Propelled Towards a People-Centered Transnational Legal Order?, 9 Am. U. J. Int'l \& Pol'y 1, 8.

Human Rights First (2003): Nongovernmental Organizations Welcome the New U.N. Norms on Transnational Business - Press Statement (Aug. 13, 2003), http://www.human rightsfirst.org/workers_rights/wr_other/wr_press_st_081303.htm.

Human Rights Watch (2004): The U.N. Norms: Towards Greater Corporate Accountability: Statement on the United Nations Norms on the Responsibilities of Transnational Corporations and Other Business Enterprises with Regard to Human Rights to the Office of the United Nations High Commissioner for Human Rights (Sept. 30, 2004), http://hrw.org/english/docs/2004/09/30/global9446.htm.

International Convention on the Elimination of All Forms of Racial Discrimination (1966): G.A. res. 2106 (XX), Annex, 20 U.N. GAOR Supp. (No. 14), U.N. Doc. A/6014, 660 U.N.T.S. 195, entered into force Jan. 4, 1969.

International Covenant on Civil and Political Rights (1966): G.A. res. 2200A (XXI), 21 U.N. GAOR Supp. (No. 16) at 52, U.N. Doc. A/6316, 999 U.N.T.S. 171, entered into force Mar. 23, 1976.

Kinley, D./ Tadaki, J. (2004): From Talk to Walk: The Emergence of Human Rights Responsibilities for Corporations at International Law, 44 Virginia. J. Int'l L. 931.

Koh, H. H. (2004): Separating Myth from Reality about Corporate Responsibility Litigation, 7 J. Int'l Econ. L. 263. 
Korten, D. (1995): When Corporations Rule the World.

Kwon, H. A. (1995): Patent Protection and Technology Transfer in the Developing World: The Thailand Experience, 28 Geo. Int'l L. \& Econ. 567, 570 n.13.

Norms on the Responsibilities of Transnational Corporations and Other Business Enterprises with Regard to Human Rights (2003): U.N. Doc. E/CN.4/Sub.2/2003/12/Rev.2.

Paust, J. J. (2002): Human Rights Responsibilities of Private Corporations, 35 Vand. J. Transnat'l L. 801.

Petersmann, E. U. (2002): Time for a United Nations 'Global Compact' for Integrating Human Rights into the Law of Worldwide Organizations: Lessons from European Integration, 13 Eur. J. Int'l L. 621.

Taylor, K. M. (2004): Thicker than Blood: Holding Exxon Mobil Liable for Human Rights Violations Committed Abroad, 31 Syracuse J. Int'l. L. \& Com. 273.

U.N. (2005): Doc. E/CN.4/2005/91.

Universal Decleration of Human Rights 1948: G.A. res. 217A (III), U.N. Doc A/810.

Weissbrodt, D./ Kruger, M. (2003): Norms on the Responsibilities of Transnational Corporations and Other Business Enterprises with Regard to Human Rights, 97 A.J.I.L. 901, 904-07. 